\title{
Antibodies to herpes simplex virus type I in intraocular fluids of patients with acute retinal necrosis
}

\author{
N SARKIES,' Z GREGOR,' T FORSEY,' AND S DAROUGAR \\ From 'Moorfields Eye Hospital, London, and the ${ }^{2}$ Institute of Ophthalmology, Judd Street, London
}

SUMmARY The intraocular fluids and sera from three patients with acute retinal necrosis (ARN) and from 120 age-matched controls were tested for the presence of antibodies to herpes simplex virus type I (HSV-I). Antibodies to HSV-I were detected in both intraocular fluids and sera of two cases, and in intraocular fluids alone in one case of ARN. Among 120 control patients undergoing routine intraocular surgery antibodies to HSV-I were detected in the sera of $85(79.2 \%)$ but in the intraocular fluids of only two $(1.7 \%)$. The presence of antibody within the eye may indicate local antibody production, antibody sequestration within the eye, or damage to the blood ocular barrier.

Recent interest in acute retinal necrosis (ARN) has drawn attention to its similarities with viral retinitis. The fundal appearances in $A R N^{1}$ are similar to the retinitis of herpes simplex virus infection in neonates ${ }^{2}$ or the retinitis of cytomegalic inclusion disease. ${ }^{3}$

Histological evidence of viral infection in ARN was obtained by Cuthbertson et al. from an enucleated eye. ${ }^{4}$ Electron microscopy of the retina revealed viral particles of the herpes virus group. Serological studies in their patient showed the presence of antibody cross-reacting to all four types of the herpes virus. But no significant change in antibody titre was detected between the acute and convalescent sera. The authors suggested that the absence of rising antibody titre was due to localisation of the infection to the eye.

In two cases of ARN reported by Peyman et al. ${ }^{5}$ immunofluorescent staining of the vitreous aspirate was positive with antiherpes simplex virus polyclonal antibody. Vitreous cultures were negative for viruses. In one of these cases antibodies to herpes simplex virus, cytomegalovirus, varicella zoster virus, Epstein-Barr virus, and variola were detected in the vitreous aspirate at low titres. However, to our best knowledge there have been no reports on the levels of these viral antibodies in intraocular fluids of unaffected patients.

We have studied antibodies to herpes simplex virus type I (HSV-I) in the blood and intraocular fluids of three patients with ARN. To establish a baseline we

Correspondence to Mr N J C Sarkies, FRCS, Department of NeuroOphthalmology, National Hospital for Nervous Diseases, Queen Square, London WC1N 3BG. also studied blood and intraocular fluid from control patients who were undergoing routine intraocular surgery with no evidence of HSV infection.

\section{Materials and methods}

A history of recent cold sores or genital ulceration was sought in each patient. A full ophthalmic and general examination was performed and included the recording of visual acuities and detection of any signs of intraocular inflammation in each eye. A full general examination was carried out, in particular with a search for evidence of oral or genital ulceration.

Two patients with ARN underwent vitrectomy for the treatment of complicated retinal detachment; samples of intraocular fluids were taken during this procedure. In the third case of ARN aqueous was sampled by a diagnostic tap of the anterior chamber.

In control patients intraocular fluid samples were taken peroperatively in such a way as to ensure that the samples were not contaminated by blood. Aqueous was collected from patients undergoing trabeculectomy or routine cataract extraction. When the anterior chamber was first opened, a sterile sponge measuring approximately $5 \times 2 \times 1 \mathrm{~mm}$ (Spontex Ltd) was saturated with aqueous (approximately $0.05 \mathrm{ml}$ of fluid being collected). The sponge was then placed in a tightly stoppered dry plastic capsule and stored at $+4^{\circ} \mathrm{C}$ until transferred to the laboratory.

Vitreous was collected via a two-way tap inserted in the aspiration line from the Ocutome vitrectomy 
Table 1 HSV-I IgG antibodies detected in serum and intraocular fluids of three patients with acute retinal necrosis

\begin{tabular}{lllll}
\hline & Serum & Aqueous & $\begin{array}{l}\text { Subretinal } \\
\text { fluid }\end{array}$ & Vitreous \\
\hline Patient 1 & $1: 128$ & & $1: 128$ & \\
Patient 2 & 0 & & $1: 16$ & $1: 16$ \\
Patient 3 & $1: 32$ & $1: 32$ & & \\
\hline
\end{tabular}

machine. A $1.0 \mathrm{ml}$ insulin type syringe was used to withdraw a specimen from the tubing.

Subretinal fluid was collected by saturating a sterile sponge of the type used for the collection of aqueous.

Tears were collected from the conjunctival sac of the fellow eye during surgery by means of a dry cellulose sponge. In the patients with ARN and the patients undergoing routine intraocular surgery blood was withdrawn on the same day as intraocular fluid was collected. All specimens were tested for type specific antibodies to HSV-I by an indirect immunofluorescence test. ${ }^{6}$ Sera were tested for specific IgG at $1 / 16$ or greater and for IgM at $1 / 8$ or above. Other specimens were tested for specific IgG and $\operatorname{IgA}$ at $1 / 8$ or greater.

\section{Results}

Antibody findings in three patients with acute retinal necrosis are shown in Table 1.

CASE 1

This 55-year-old woman was well until April 1982,

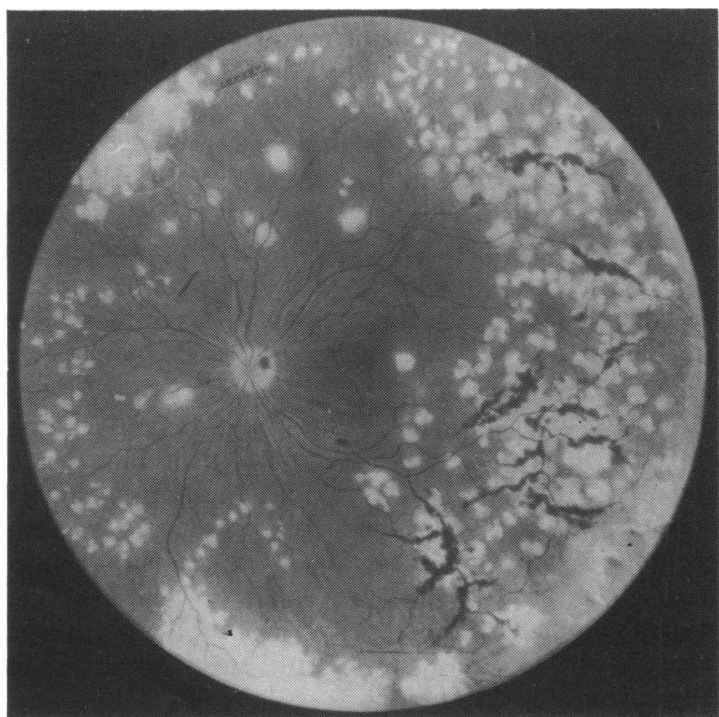

Fig. 1 Drawing of right fundus showing peripheral retinal necrosis and haemorrhage. when she suddenly developed drowsiness and dysphasia. A diagnosis of herpes encephalitis was made, and she was treated with intravenous acyclovir and then systemic steroids, in reducing dosage. Three months later she complained of blurred vision in her left eye, and examination showed panuveitis with ARN (Fig. 1). Serum IgG to HSV-I was positive at a titre of $1: 16$.

She was treated with systemic steroids. Four weeks later she developed a total retinal detachment in her left eye (Fig. 2). A left vitrectomy, lensectomy, and silicone oil: fluid exchange were performed. Serum IgG antibody to HSV-I had risen to a titre of 1:128. HSV-I IgG was also present at a titre of 1:128 in subretinal fluid.

\section{CASE 2}

This was a 56-year-old woman who was well until she developed blurred vision in her right eye in September 1982. A diagnosis of ARN was made, and she was treated with intravenous acyclovir. Two months later a total retinal detachment developed in her right eye. A vitrectomy and gas: fluid exchange was performed. Serum IgG antibody to HSV-I was negative. However, IgG to HSV-I was present at a titre of $1: 16$ in the subretinal fluid and vitreous.

\section{CASE 3}

This was a 70-year-old man who was well until he developed pain in his left eye in September 1982. A diagnosis of ARN was made, and he was treated with intravenous acyclovir. IgG to HSV-I was present in his serum at a titre of 1:32. A diagnostic tap was performed on the anterior chamber, and IgG to HSV-I was found in the aqueous at a titre of $1: 32$.

We studied 120 consecutive patients undergoing routine anterior or posterior segment intraocular

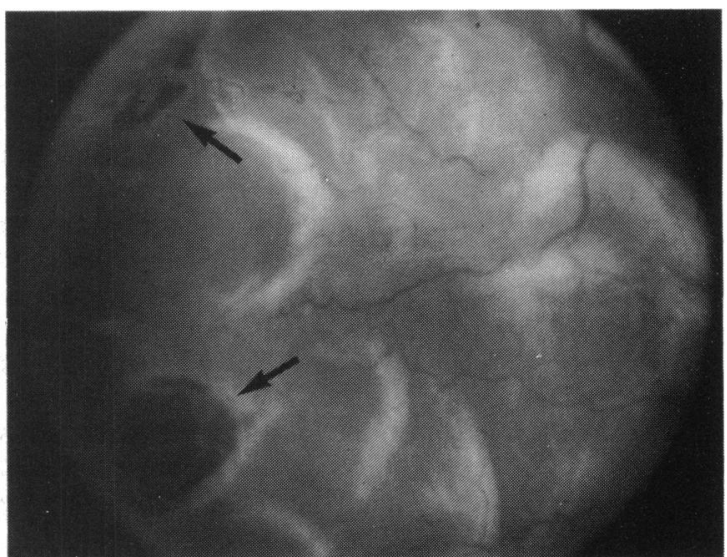

Fig. 2 Fundus photograph of peripheral retina showing retinal holes (arrows) and detached retina. 
Table 2 HSV-I IgG antibodies detected in serum, tears, and aqueous of 100 patients undergoing routine intraocular surgery

\begin{tabular}{lcc}
\hline & No. negative & $\begin{array}{l}\text { No. with antibodies } \\
\text { to HSV-I }\end{array}$ \\
\hline Serum & 19 & 81 \\
Tears & 100 & 0 \\
Aqueous & 100 & 0 \\
\hline
\end{tabular}

Table 3 HSV-IIgG antibodies detected in serum, tears, and vitreous of 10 patients undergoing routine vitrectomy

\begin{tabular}{lcl}
\hline & No. negative & $\begin{array}{l}\text { No. with antibodies } \\
\text { to HSV-I }\end{array}$ \\
\hline Serum & 3 & 7 \\
Tears & 10 & 0 \\
Vitreous & 9 & 1 \\
\hline
\end{tabular}

Table $4 \quad H S V-I I g G$ antibodies detected in serum, tears, and subretinal fluid of 10 patients undergoing routine drainage of subretinal fluid

\begin{tabular}{lcl}
\hline & No. negative & $\begin{array}{l}\text { No. with antibodies } \\
\text { to HSV-I }\end{array}$ \\
\hline Serum & 3 & 7 \\
Tears & 10 & 0 \\
Subretinal fluid & 9 & 1 \\
\hline
\end{tabular}

surgery between 24 January 1983 and 31 July 1983. Their average age was 68 (range 14 to 90 ). There were 56 males and 64 females. Patients with a history of trauma or diabetes mellitus were excluded because of the increased incidence of vitreous haemorrhage in these conditions. None of the patients gave a history or showed signs of recent oral or genital ulceration and none had evidence of recent intraocular inflammation.

The patients studied may be considered in three groups depending on whether aqueous, vitreous, or subretinal fluid was collected in addition to tears and blood (Tables 2-4).

Aqueous was collected from 100 patients. No antibodies to HSV-I were found in aqueous or tears. Antibodies to HSV-I were found in the sera of 81 (Table 2).

Vitreous was collected from 10 patients. Serum antibody to HSV-I was found in seven patients. No antibody to HSV-I was found in tears. In one patient IgG to HSV-I was found at a titre of $1: 8$ in the vitreous. Concurrent serum IgG was 1/64 (Table 3).

Subretinal fluid was collected from 10 patients. In seven patients serum antibody to HSV-I was positive. In none of the tears collected were antibodies to HSV-I present. In one patient subretinal fluid antibody to HSV-I was present at a titre of $1: 32$; concurrent serum titre in this patient was also 1:32 (Table 4).

\section{Discussion}

We found antibody to HSV-I in intraocular fluids of three patents with ARN and in two out of $120(1.7 \%)$ of controls.

We consider that there are four possible explanations for the presence of antibody in intraocular fluids. First, the antibody may be produced within the eye. Secondly, it may be produced elsewhere but sequestered in the eye. Thirdly, it may leak from the serum when the blood-ocular barrier is damaged. Fourthly, it may leak into the eye during the sampling procedure.

The presence of higher antibody levels in the aqueous than in the serum has been cited as proof of local antibody production within the eye. Felberg et al reported five cases of ocular toxocariasis in which antibody titres to toxocara canis in the aqueous were significantly higher than the serum. ${ }^{7}$ They assert that the presence of plasma cells in the eosinophilic abscess which characterises nematode endophthalmitis is suggestive of local production of antibody.

However, there are difficulties making direct comparisons between serum and aqueous without taking account of the different concentrations of IgG. Pedersen and Lorentsen-Styr compared aqueous and serum concentrations of antibody against toxoplasma gondii in 10 patients with active retinochoroiditis. ${ }^{8}$ According to a formula derived from Desmonts," they calculated the aqueous humour antibody coefficient:

$$
\text { Coefficient }=\text { antibody } \text { titre } \frac{\text { aqueous }}{\text { serum }} \times \text { globulin } \frac{\text { serum }}{\text { aqueous }}
$$

A titre greater than 1 indicated that aqueous humour globulins were richer in toxoplasma antibodies than the serum. In six out of 10 patients the antibody aqueous humour coefficient was significantly raised. This finding suggests local antibody production within the eye.

There have also been reports of autoantibody detected within the aqueous but not in the serum of patients with uveitis. In two patients with chronic anterior uveitis and Still's disease antinuclear antibodies were present in the aqueous but not in the blood. ${ }^{10}$ Rheumatoid factor was detected in aqueous but not serum of five patients with endogenous uveitis. " However, in all these circumstances it is possible that antibody had been sequestered in the eye rather than produced there.

There is indirect evidence of leak of antibody across a damaged blood ocular barrier. The uveal 
vessels have been shown to exert a degree of selectivity when albumin-bound trypan blue and colloidal carbon were used as markers. ${ }^{12}$ The integrity of this barrier could be compromised after local application of histamine. ${ }^{13} \mathrm{~A}$ similar leak may occur after any episode of intraocular inflammation. Pedersen and Lorentsen-Styr noted a high level of IgG in the aqueous of a patient with active uveitis. ${ }^{8}$ Antibody leak would certainly explain the finding of antibody to HSV-I in two patients with ARN (cases 1 and 3). In one patient, case 2, antibody to HSV-I was not detected in the serum, implying there was local antibody production or sequestration. However, in this case the titre of antibody in the subretinal fluid and vitreous was low.

Though antibody to HSV-I was present in the sera of 95 out of $120(79 \%)$ patients undergoing routine intraocular surgery, it was present in the intraocular fluids of only two $(1.7 \%)$ patients. This makes it highly unlikely that the detection of antibody in intraocular fluids was due to contamination during the sampling procedure.

In conclusion, we consider that antibody in intraocular fluid may result from local antibody production or sequestration or damage to the blood ocular barrier. To establish which process is responsible studies of intraocular fluids in inflamed eyes are required. The presence of antibody to HSV-I in the intraocular fluid of patients with ARN is highly suggestive evidence that this virus causes this disease.

We thank the surgeons at Moorfields for allowing us to study their cases, Mr Richard Dewhirst for preparation of the illustrations, and Miss Josephine Lace for secretarial assistance.

\section{References}

1 Young NJA, Bird AC. Bilateral acute retinal necrosis. Br J Ophthalmol 1978; 62: 581-90.

2 Cogan DC, Kuwabara T, Young GF, Knox DL. Herpes simplex retinopathy in an infant. Arch Ophthalmol 1964; 72: 641-5.

3 Pollard RB, Egbert PR, Gallagher JG, et al. Infections with cytomegalovirus in adults and the natural history and treatment of cytomegalovirus retinitis. In: Sundmacher R, ed. Herpetische Augenerkrankungen Munich: Bergen, 1981: 481-93.

4 Culbertson WW, Blumenkranz MS, Haines $\mathrm{H}$, et al. The acute retinal necrosis syndrome: part 2 . Histopathology and aetiology. Ophthalmology (Rochester) 1982; 82: 1317-25.

5 Peyman GA, Goldberg MF, Uninsky E, et al. Vitrectomy and intravitreal antiviral therapy in acute retinal necrosis. Arch Ophthalmol 1984; 102: 1618-21.

6 Forsey T, Darougar S. Indirect micro-immunofluorescence test for detecting type-specific antibodies to herpes simplex virus. $J$ Clin Pathol 1980; 33: 171-6.

7 Felberg NT, Shields JA, Federman JL. Antibody to Toxocara canis in the aqueous humor. Arch Ophthalmol 1981;99: 1563-4.

8 Pedersen OO, Lorentsen-Styr A. Antibodies against Toxoplasma gondii in the aqueous humour of patients with active retinochoroiditis. Acta Ophthalmol (Kbl) 1981; 59: 719-26.

9 Desmonts G. Definite serological diagnosis of ocular toxoplasmosis. Arch Ophthalmol 1966; 76: 839-51.

10 Rahi AHS, Kanski JJ, Fielder A. Immunoglobulins and antinuclear antibodies in aqueous humour from patients with juvenile 'rheumatoid' arthritis (Still's disease). Trans Ophthalmol Soc UK 1977; 97: 217-21.

11 Dernouchamps JP, Vaerman JP, Michiels J, Masson PL. Immune complexes in the aqueous humor and serum. Am J Ophthalmol 1977; 84: 24-31.

12 Cunha-Vaz JG, Shakib M, Ashton N. Studies on the permeability of the blood-retinal barrier. Br J Ophthalmol 1966; 50: 441-53.

13 Ashton N, Cunha-Vaz JG. Effect of histamine on the permeability of the ocular vessels. Arch Ophthalmol 1965; 73: 211-23.

Accepted for publication 30 May 1985. 